\title{
Effect of Sea Breeze on Air Pollution in the Greater Athens Area. Part I: Numerical Simulations and Field Observations
}

\author{
Alain Clappier and Alberto Martilli \\ École Polytechnique Fédérale de Lausanne, Laboratoire de la Pollution Atmosphérique et Sol, \\ Lausanne, Switzerland \\ Paola Grossi, Philippe Thunis, and Francesco Pasi \\ Joint Research Centre, Environment Institute, Ispra, Italy \\ Bernd C. Krueger and Bertrand Calpini \\ École Polytechnique Fédérale de Lausanne, Laboratoire de la Pollution Atmosphérique et Sol, \\ Lausanne, Switzerland \\ GIOVANNI GRAZIANI \\ Joint Research Centre, Environment Institute, Ispra, Italy \\ HUBERT VAN DEN BERGH \\ École Polytechnique Fédérale de Lausanne, Laboratoire de la Pollution Atmosphérique et Sol, \\ Lausanne, Switzerland \\ (Manuscript received 9 March 1998, in final form 1 April 1999)
}

\begin{abstract}
Numerical simulations compared with field measurements are used to explain the effect of sea breezes on photochemical smog episodes in Athens during the Mediterranean Campaign of Photochemical Tracers on 1214 September 1994. The numerical simulations, performed using a nonhydrostatic vorticity mesoscale model coupled to the Lurmann-Carter-Coyner photochemical module, are compared with ground-based lidar and aircraft measurements. The current analysis shows that the three selected days include the two main summertime flow patterns characteristic of the Athens peninsula, each of which lead to significantly different pollution amounts. On 12 and 13 September, a strong, northerly synoptic wind reduces the inland penetration of the sea breeze so that ozone concentrations within the greater Athens area remained low. In contrast, the weaker synoptic forcing on 14 September allowed the development of sea breezes over the whole peninsula and high ozone concentrations were found north and east of the city. An analysis based on pollution amounts and wind patterns is carried out to divide the peninsula into regions, each of which corresponds to a specific pollutant behavior.
\end{abstract}

\section{Introduction}

In the last decades, the population of the city of Athens has increased to 4 million inhabitants in an area of about $500 \mathrm{~km}^{2}$. Today, more than half of both the registered cars and industrial activities in Greece are concentrated in the greater Athens area (GAA) (Fig. 1). In the period of 1984-89, photochemical smog episodes became more and more frequent. For example, in 1988

Corresponding author address: Alain Clappier, EPFL, DGR-LPAS, CH-1015, Lausanne, Switzerland.

E-mail: alain.clappier@epfl.ch at Liosia, one of the northern Athens suburbs, the 8-h average ozone $\left(\mathrm{O}_{3}\right)$ concentration exceeded the health protection threshold prescribed by the European Community $\left(110 \mu \mathrm{g} \mathrm{m}^{-3}\right)$ on 140 days (Moussiopoulos et al. 1995). For these reasons, several air quality studies (both experimental and numerical) were performed in the 1980s and 1990s in GAA to understand the mechanism of ozone formation in this region and to determine abatement strategies.

In 1990, the Athenian Photochemical Smog Intercomparison of Simulations project, which was organized within the European Experiment on the Transport and Transformation of Environmentally Relevant Trace Constituents in the Troposphere over Europe, used sev- 


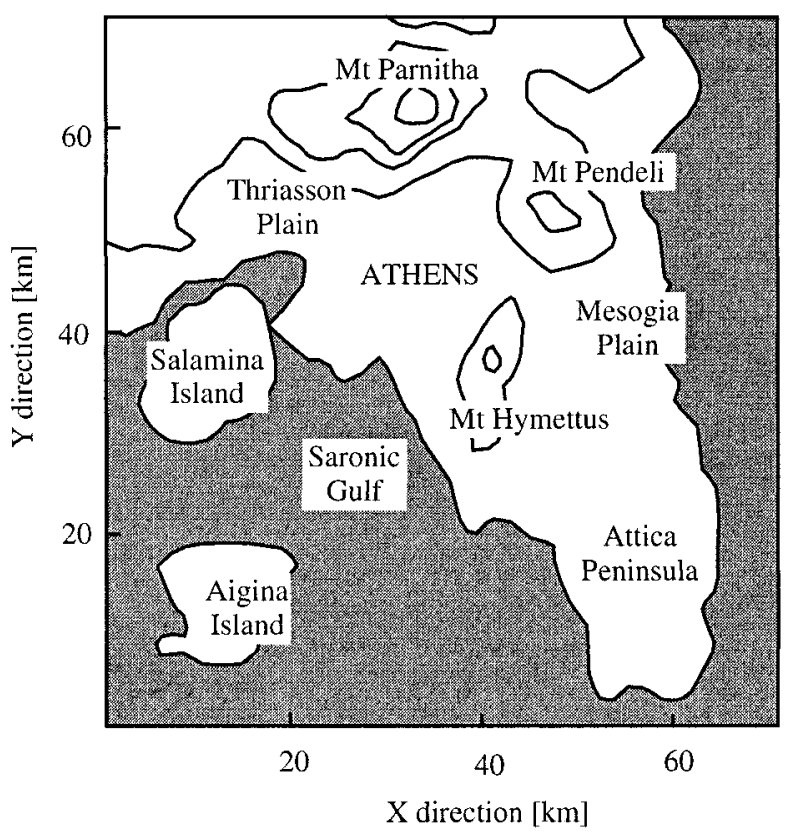

FIG. 1. Greater Athens area map. The shaded area represents the sea, and the contours correspond to the altitudes of $0,300,600$, and $1000 \mathrm{~m}$ above sea level.

eral state-of-the-art air pollution models to simulate wind flow and photochemical smog formation in Athens. The aim was the intercomparison of the results and the performance assessment of these models (e.g., Moussiopoulos et al. 1995; Varvayanni et al. 1995; Nester 1995; Melas et al. 1995; Grossi et al. 1996).

Another important campaign, the Mediterranean Campaign of Photochemical Tracers-Transport and Chemical Evolution (MEDCAPHOT-TRACE), took place in September 1994. Its aim was to investigate the capability of models to predict photochemical pollutant concentrations both at ground level and aloft (Ziomas et al. 1998; Svensson 1995). All these studies have shown that the photochemical smog intensity over Athens is enhanced by the coincidence of the following factors.

1) Large emissions of nitrogen oxides $\left[\mathrm{NO}_{\mathrm{x}}\right.$ : nitric oxide $(\mathrm{NO})+$ nitrogen dioxide $\left.\left(\mathrm{NO}_{2}\right)\right]$ and volatile organic compounds (VOC) in the city. Road traffic is responsible for three-fourths of the total $\mathrm{NO}_{\mathrm{x}}$ emissions and nearly two-thirds of the VOC emissions (Moussiopoulos et al. 1995). Furthermore, the average area density of pollutant emissions in Athens is six times larger than it is in Los Angeles [Mantis et al. (1992); although Los Angeles covers a larger area], a classical example of photochemical smog.

2) Clear skies and strong solar radiation, which drive the photochemical mechanisms and create ozone.

3) A critical balance between synoptic forcing and local sea-breeze systems, which enhance pollutant recirculation.

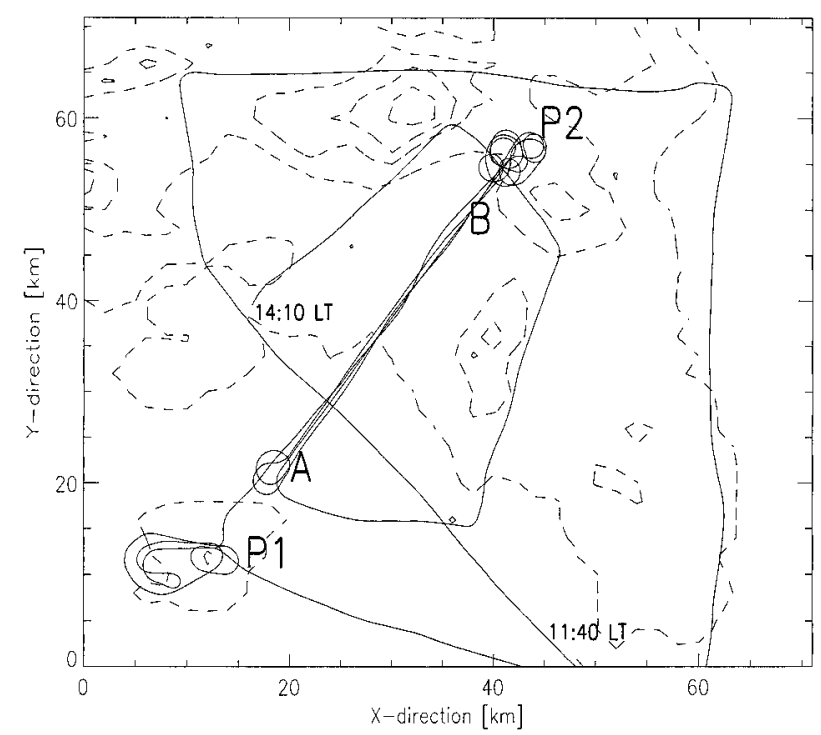

FIG. 2. Horizontal projection of the $12 \mathrm{Sep}$ flight path between 1140 and 1410 LT. Here P1 and P2 indicate the two profile locations. Cross sections were performed between A and B.

The conditions in Athens are similar to those in Los Angeles, which also is characterized by land-sea-breeze recirculation and clear skies (e.g., Businger 1975; McRae et al. 1981; Lu and Turco 1996) but has more dense emissions.

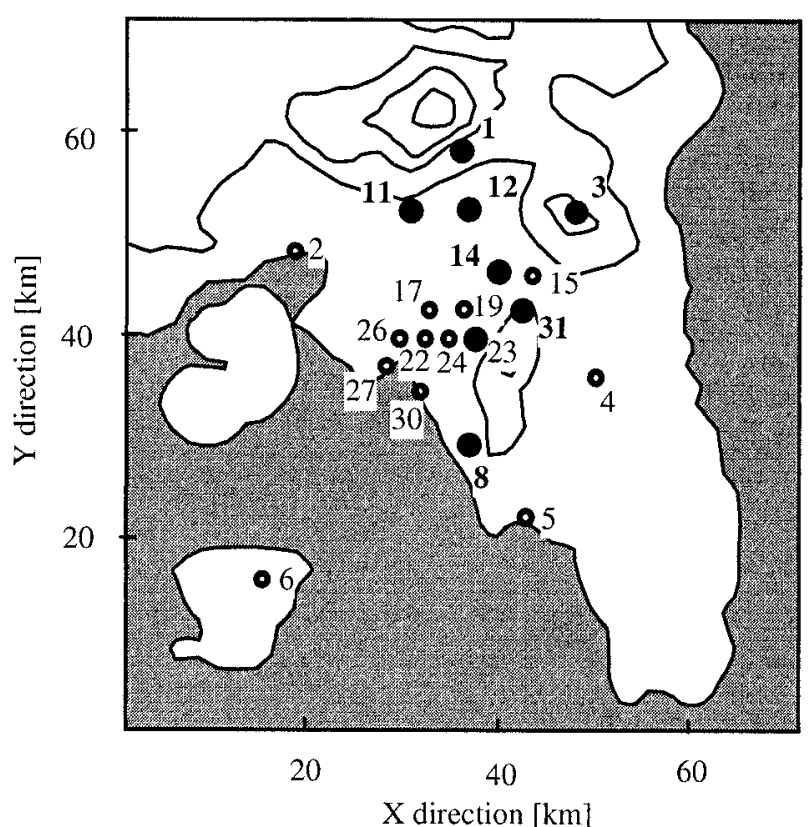

FIG. 3. Model domain and location of surface stations. The large circles denote stations where more than $90 \mathrm{ppb}$ of ozone were measured on 14 Sep. Station names: Thrakomakedones (1), Elefsis (2), Pendeli (3), Spata (4), Varkiza (5), Aigina (6), Helleniko airport (8), Liosa (11), Lykobrisi (12), Marousi (14), Peristeri (15), National Road (17), Patision (19), Geoponiki (22), Lykabetus Hill (23), Athens Street (24), Rentis (26), Pireus (27), Nea Smirni (30), and Demokritos (EPFL) (31). 
In this paper, results from the dynamical/photochemical topographic vorticity-mode mesoscale (TVM) model using the Lurmann-Carter-Coyner (LCC; Lurmann et al. 1987) chemical mechanism are compared with measurements (ground-based, aircraft, and lidar) made from 12 to 14 September 1994 during the MEDCAPHOT-TRACE campaign. This 3-day period is chosen because of the wide range of measurements that are available and because it includes two of the main characteristic synoptic summer situations in the Athens area. These typical situations are described by Kallos (1993). When a high pressure system covers the eastern Mediterranean and the Balkans up to the Black Sea, a thermal low pressure develops during the day over the Anatolian Plateau (southeast of the Balkans and the Black Sea) because of ground heating. The balance between these two systems determines the weather conditions over eastern Greece and the Aegean Sea. When the high pressure system strengthens, it extends westward and the pressure gradient across the Aegean Sea weakens. Consequently, the northerly synoptic wind over the Athens basin becomes weaker and a local, thermal sea-landbreeze circulation develops (situation on 14 September). In contrast, when the high pressure system weakens, the thermal low over the Anatolian Plateau extends westward and the pressure gradient over the Aegean Sea then becomes stronger. During these days, northerly Aegean Sea winds (Etesian winds) are strong and reduce the local sea-breeze extention (situation on 12 and 13 September).

\section{Description of measurements}

Only a brief description of the measurements made during the 3-day period of interest is presented here. For more details, see the MEDCAPHOT measurement database provided by Ziomas et al. (1998).

The aircraft measurements of $\mathrm{O}_{3}, \mathrm{NO}$, and $\mathrm{NO}_{2}$ (Klemm et al. 1998) were taken by a Dornier 228 twinengine, turboprop research aircraft operated by the Deutsches Zentrum für Luft- und Raumfahrt, Oberpfaffenhofen, Germany, and instrumented for chemical measurements by the Fraunhofer-Institut für Atmosphärische Umweltforschung, Garmisch-Partenkirchen, Germany. The system sampling time is $1 \mathrm{~Hz}$, and the data presented here are averaged over $5 \mathrm{~s}$. On 12 September, the aircraft flew over the domain between 1140 LT and 1410 LT $($ LT $=$ local summer time $=$ UTC + $3 \mathrm{~h}$ ). Two vertical profiles were available in the northeast and southwest parts of the domain, and several horizontal crosswind flights were performed at different altitudes. The flight trajectories are shown in Fig. 2.

A mobile differential absorption lidar system developed at the Swiss Federal Institute of Technology (EPFL, Lausanne, Switzerland) was used in the MEDCAPHOT-TRACE experiment to measure 3D ozone concentrations over the site of Demokritos in the northeastern part of GAA (location 31 in Fig. 3). A detailed

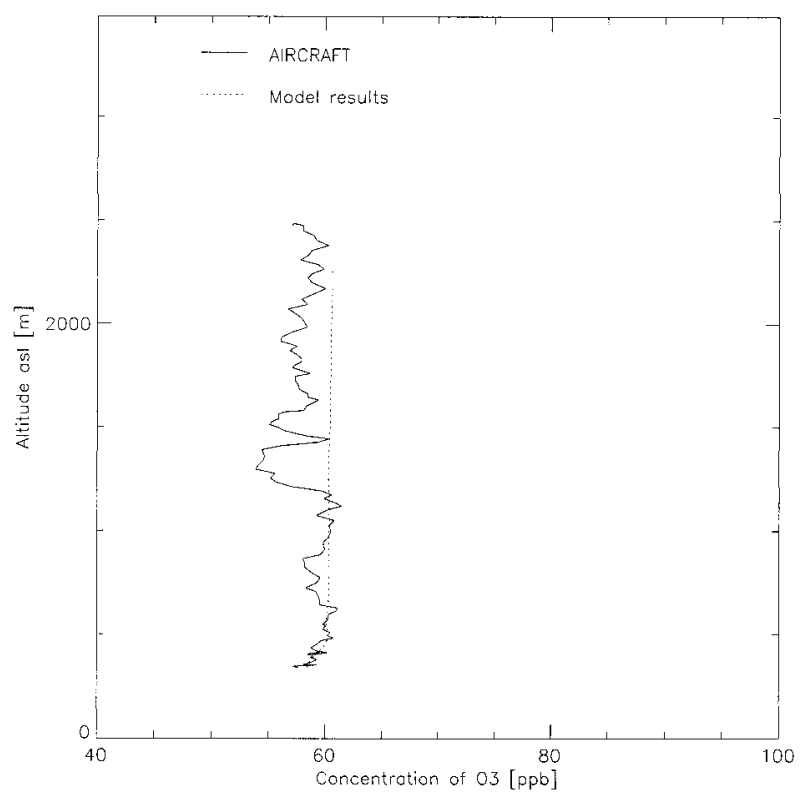

FIG. 4. Vertical ozone profile over Tatoi (P2) on 12 Sep between 1300 and 1315 LT. The solid line indicates aircraft measurements, and the dotted line shows model results.

description of system performance is presented elsewhere (Fiorani et al. 1997, 1998; Durieux et al. 1998; Schoulepnikoff et al. 1998). For the same period, diverse chemical compounds $\left(\mathrm{O}_{3}, \mathrm{NO}, \mathrm{NO}_{2}\right.$, etc. $)$ and meteorological variables (wind, temperature, relative humidity, etc.) were measured at twenty ground stations widely distributed within the domain (Fig. 3). Wind and temperature vertical profiles were taken at 0000 and 1200 UTC at Hellenikon Airport (station 8 in Fig. 3).

\section{Model description}

\section{a. Model formulation}

The model used in this study is the TVM meteorological model (Thunis 1995; Bornstein et al. 1996; Schayes et al. 1996) coupled to the California Institute of Technology (Harley et al. 1993) chemical module using the LCC chemical reactions (Lurmann et al. 1987).

\section{1) Dynamical module}

The prognostic TVM model forecasts the tropospheric dynamics using finite-difference techniques. The model numerically solves the following equations.

1) Two vorticity equations in a nonhydrostatic form. Through the use of streamvector functions, the three velocity components are recovered from vorticity values. One of the advantages of the vorticity formulation is that mesoscale pressure (the boundary conditions of which are not easy to specify) is eliminated from the set of prognostic variables. For more 

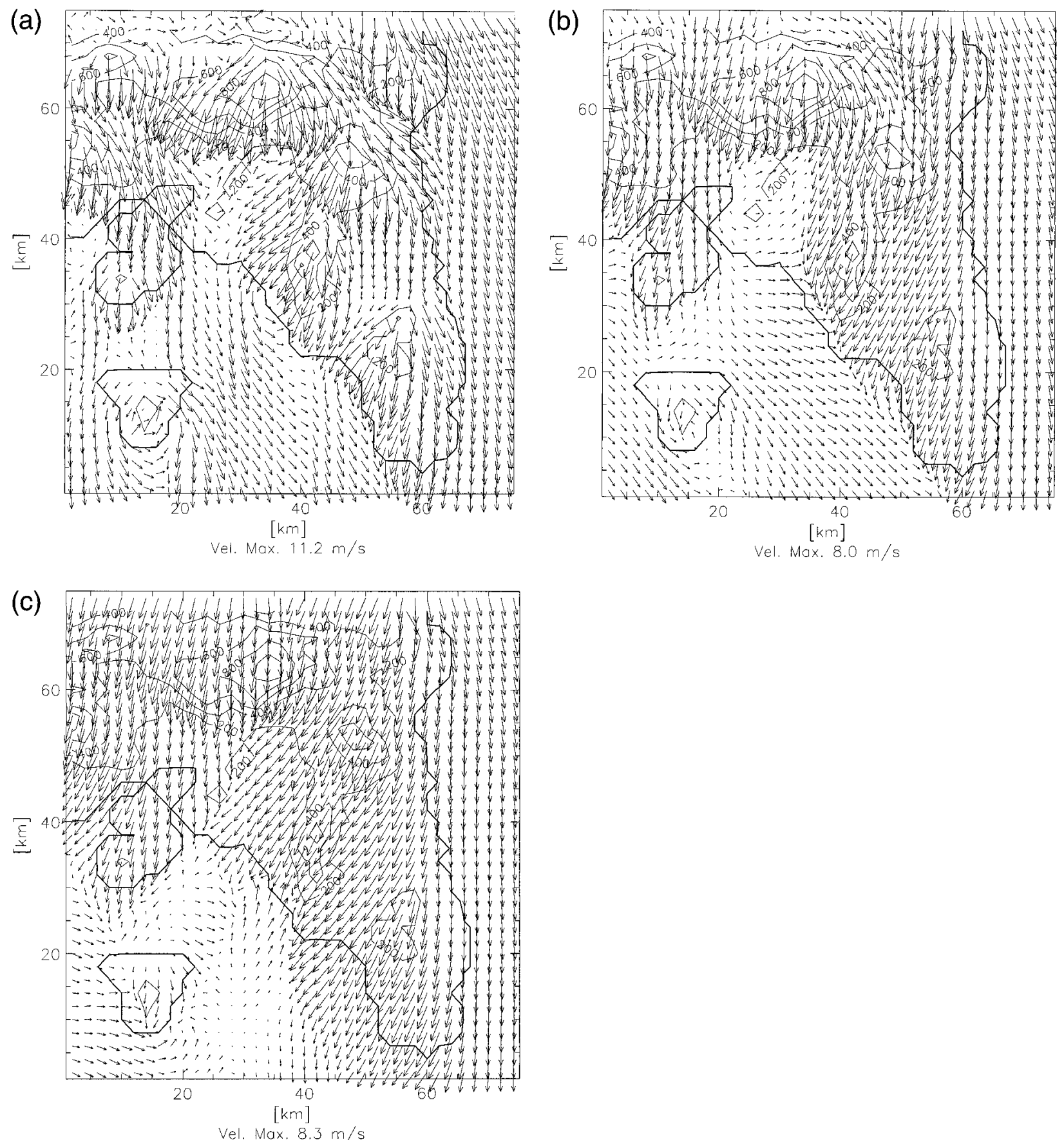

FIG. 5. Modeled wind field at $15 \mathrm{~m}$ AGL on $12 \mathrm{Sep}$ at (a) 0300, (b) 1200, and (c) 1600 LT. Scaling vector is the same for all the graphics.

details about the vorticity formulation advantages and disadvantages, see Schayes et al. (1996).

2) A thermal energy equation.

3) A specific humidity equation (in this model version, air is assumed to be unsaturated; there is no condensation and no latent heating).

4) A turbulent kinetic energy (TKE) budget equation. TKE values are used to compute the vertical tur- bulent coefficients using the Therry and Lacarrère (1983) formulation.

Transport is computed by a third-order positive definite advection scheme (Collela and Woodward 1984), known as the piecewise parabolic method, corrected for multidimensional applications (Clappier 1998). A 500 $\mathrm{m}^{2} \mathrm{~s}^{-1}$ constant horizontal diffusion coefficient is used 
(a)
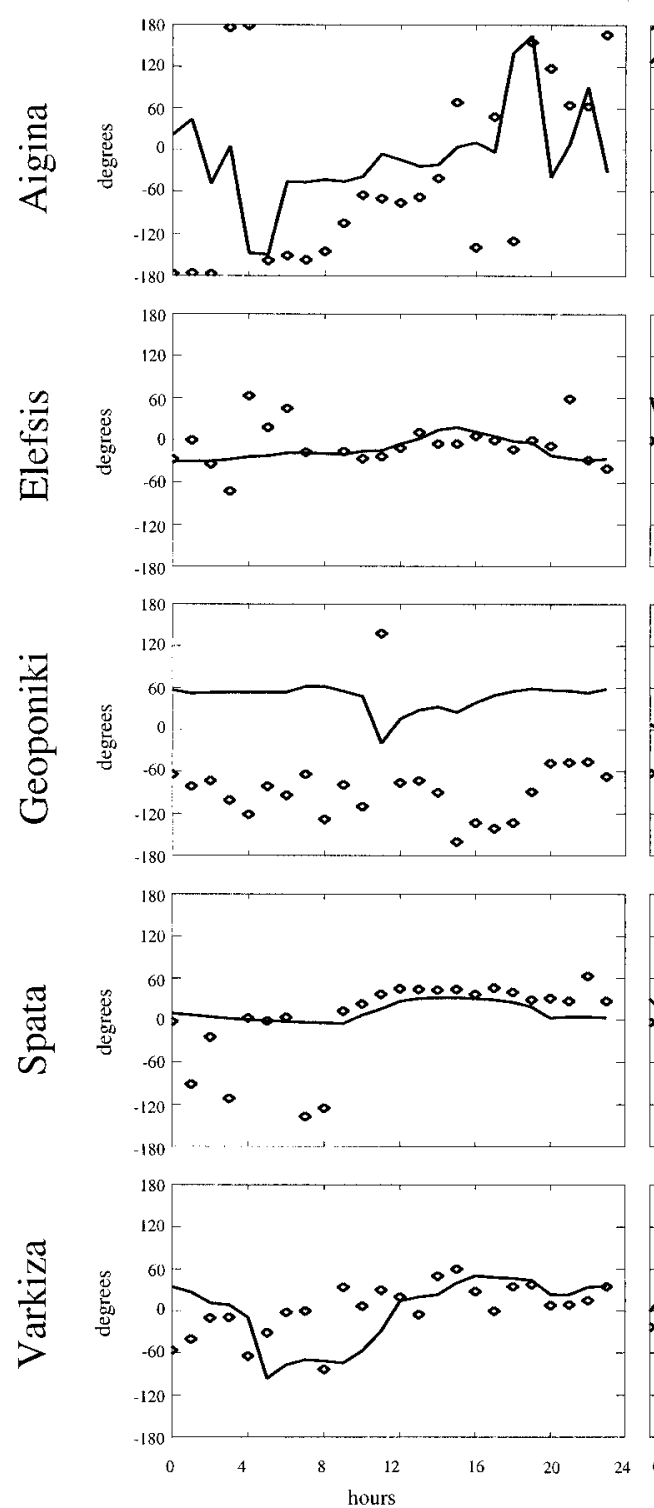

FIG. 6. Comparison between ground measurements and model calculations on 12 and 14 Sep for (a) wind direction and (b) wind speed (solid lines are model results, and diamonds are measurements). On the vertical axis, the positive (negative) values correspond to an easterly (westerly) wind. in the current calculations, based on the results of different heat-island and mountain-wave 2D cases (Thunis 1995). Analytical functions of Louis (1979) are used to compute wind velocities and temperature in the surface layer, and fluxes are computed with a soil-vegetationatmosphere transfer model (De Ridder and Schayes 1997). This module solves prognostic equations for temperature and humidity within the soil using four computational levels and accounts for the presence of vegetation. Pollutant transport uses the same advection scheme as is used in the dynamical module, and tur- bulent transport is solved in the vertical by use of the dynamic diffusion coefficients.

\section{2) Chemical module}

The LCC chemical gas-phase system (Lurmann et al. 1987) includes 44 gas-phase species (of which 35 are transported and 9 are considered to be in steady state) coupled through 106 reactions. It originally was developed to represent the photooxidation of nonmethane organic compounds (lumped into 12 precursors) and ni- 
(b)
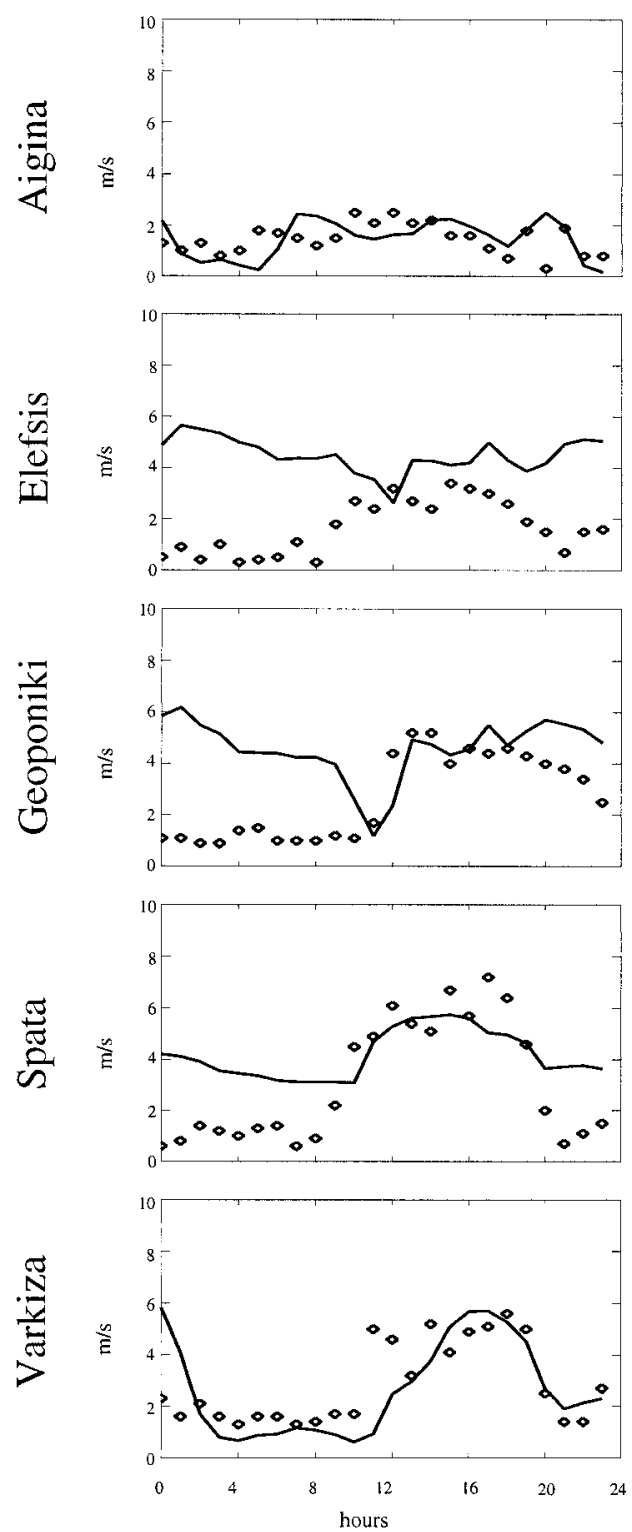

September 14
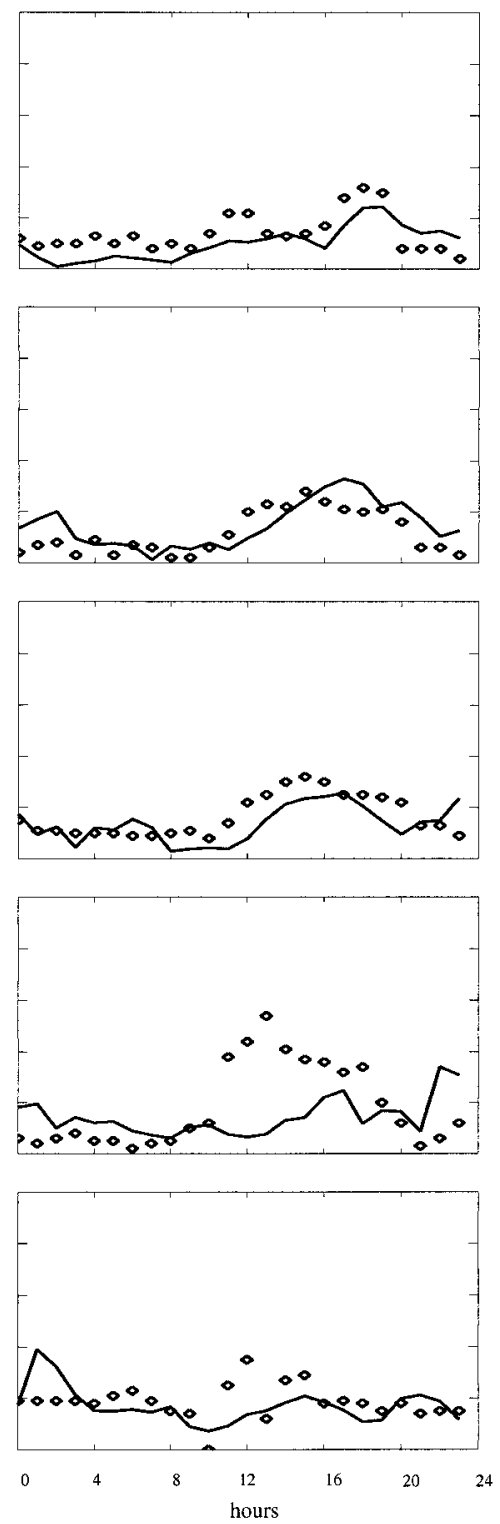

FIG. 6. (Continued)

trogen oxides in urban-scale air quality simulation models and was extended by Harley et al. (1993) to treat biogenic emissions and fuel additives explicitly. The numerical method used is the accurate and computationally efficient hybrid scheme of Young and Boris (1977). Photolysis rate constants needed for photochemical reactions are prepared by means of the System for Transfer of Atmospheric Radiation submodule (Ruggaber et al. 1994).

\section{3) Coupling technique}

A feature of the TVM-LCC model is the coupling technique between the meteorological and pollutant modules. The first one calculates wind, temperature, and turbulence fields, and the second one calculates transport and chemical transformations. The two modules run simultaneously but with different time steps. Because of different numerical stability constraints, the meteorological module needs a shorter time step than is required by the pollutant module. Meteorological variables therefore are computed and averaged over $n$ time steps of length $\Delta t_{\mathrm{dyn}}$ (dynamic time step) until the numerical stability condition [Courant-Friedrich-Levy (CFL) criterion] is reached for pollutant transport. The pollutant module is then run for a time step of length $\Delta t_{\text {trp }}=n \Delta t_{\text {dyn }}$ (transport/chemistry time step). A series of $2 \mathrm{D}$ tests has shown that this method minimizes trans- 


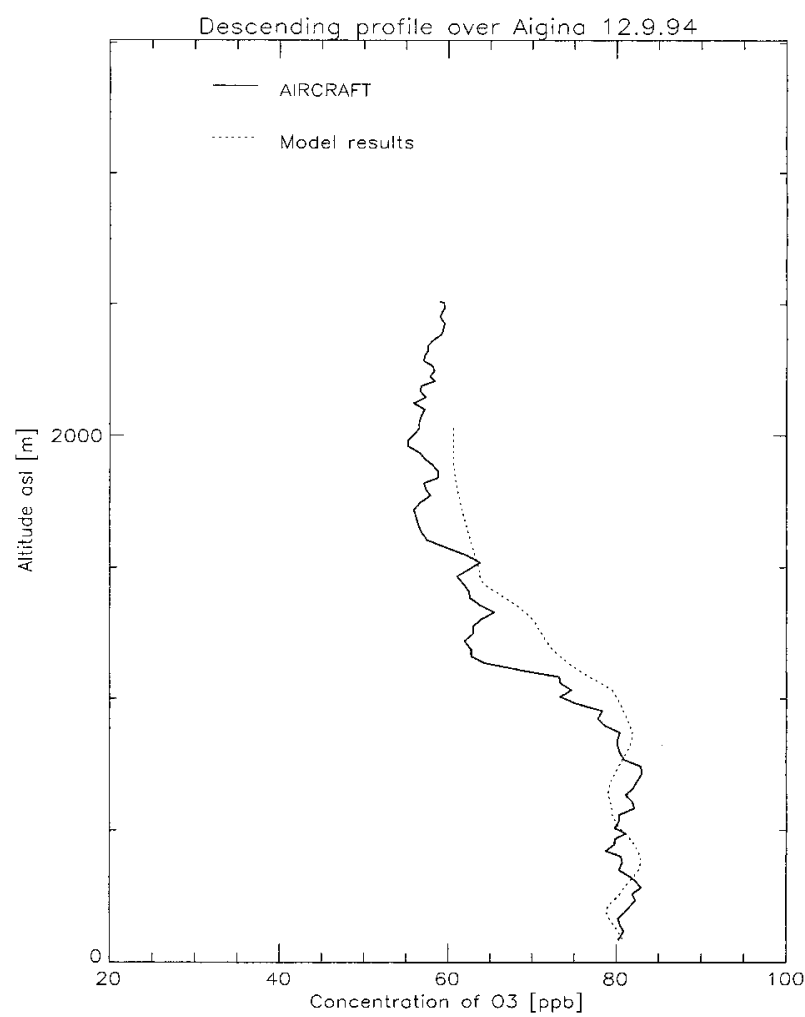

FIG. 7. Vertical profiles of ozone over Aigina (P1) on 12 Sep between 1235 and 1245 LT. The solid line depicts aircraft measurements, and the dotted line shows model results.

port calculation errors while keeping a low central processing unit time consumption. In this study, $\Delta t_{\mathrm{dyn}}$ is chosen to be $20 \mathrm{~s}$, and $\Delta t_{\text {trp }}$ is computed using the CFL criterion (180-300 s depending on wind speed).

\section{b. Model setup}

\section{1) DoMAIN}

The modeling domain (Fig. 1) is $72 \mathrm{~km} \times 72 \mathrm{~km}$ with a grid spacing of $2 \mathrm{~km} \times 2 \mathrm{~km}$ that enables the city of Athens, the Saronic Gulf, Aigina Island (to the south), Mt. Parnitha (to the north), Pendeli, and the Hymettus hills (to the east) to be distinguished clearly.

At the lateral boundaries, eight additional grid cells with a spacing ranging from 2.4 to $8.7 \mathrm{~km}$ (grid-stretching ratio of 1.2) are used to move boundaries away from the domain of interest to reduce their influence on the flow. The exact number was decided after a series of

TABLE 1. Large-scale input parameters for the meteorological simulations.

\begin{tabular}{lcc}
\hline \hline & $12 \mathrm{Sep}$ & $14 \mathrm{Sep}$ \\
\hline Geostrophic wind speed & $8 \mathrm{~m} \mathrm{~s}^{-1}$ & $2 \mathrm{~m} \mathrm{~s}^{-1}$ \\
Geostrophic wind direction & $20^{\circ}$ & $20^{\circ}$ \\
Atmospheric stability & $3.5 \mathrm{~K} \mathrm{~km}^{-1}$ & $3.5 \mathrm{~K} \mathrm{~km}^{-1}$ \\
\hline
\end{tabular}

a)

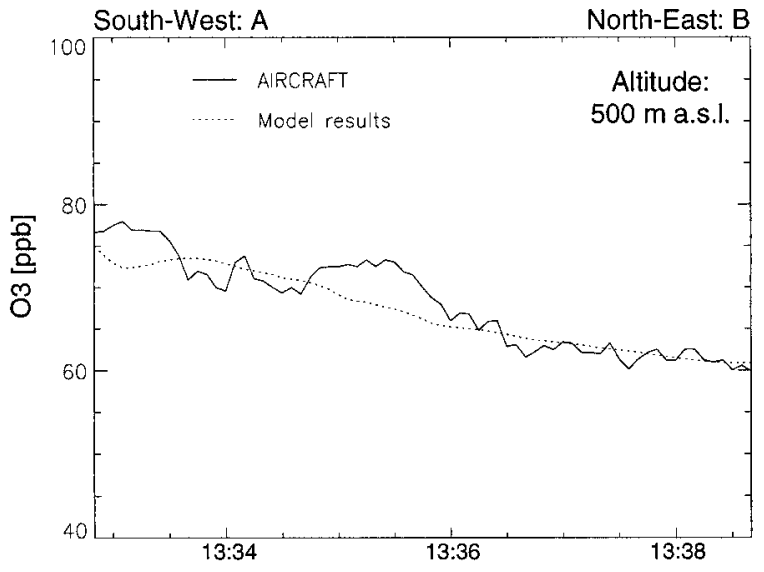

b)

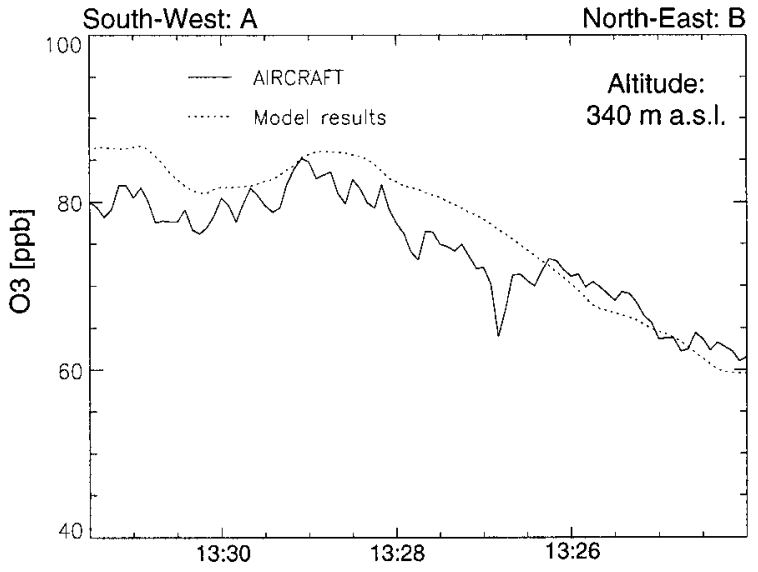

c)

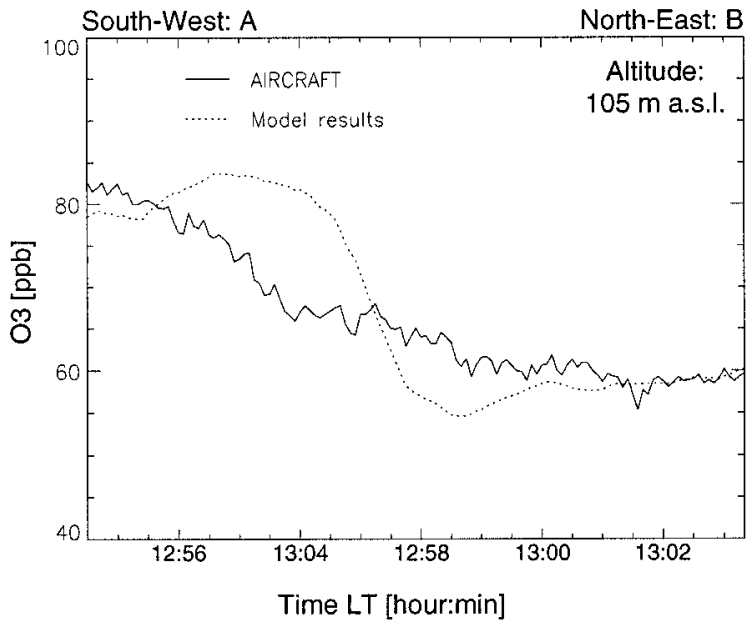

FIG. 8. Ozone measured along the horizontal flight path at different heights: (a) 500, (b) 340, and (c) $105 \mathrm{~m} \mathrm{MSL}$. Solid line shows aircraft measurements, and dotted line shows model results.

tests in which a number of additional cells (ranging from 0 to 12 ) were added at the boundaries. No significant change in the results occurred when the number of lateral additional cells was larger than eight. These additional cells lead to a total dimension of $151 \mathrm{~km} \times 151$ $\mathrm{km}$ for the domain used for the dynamics. In the vertical, 

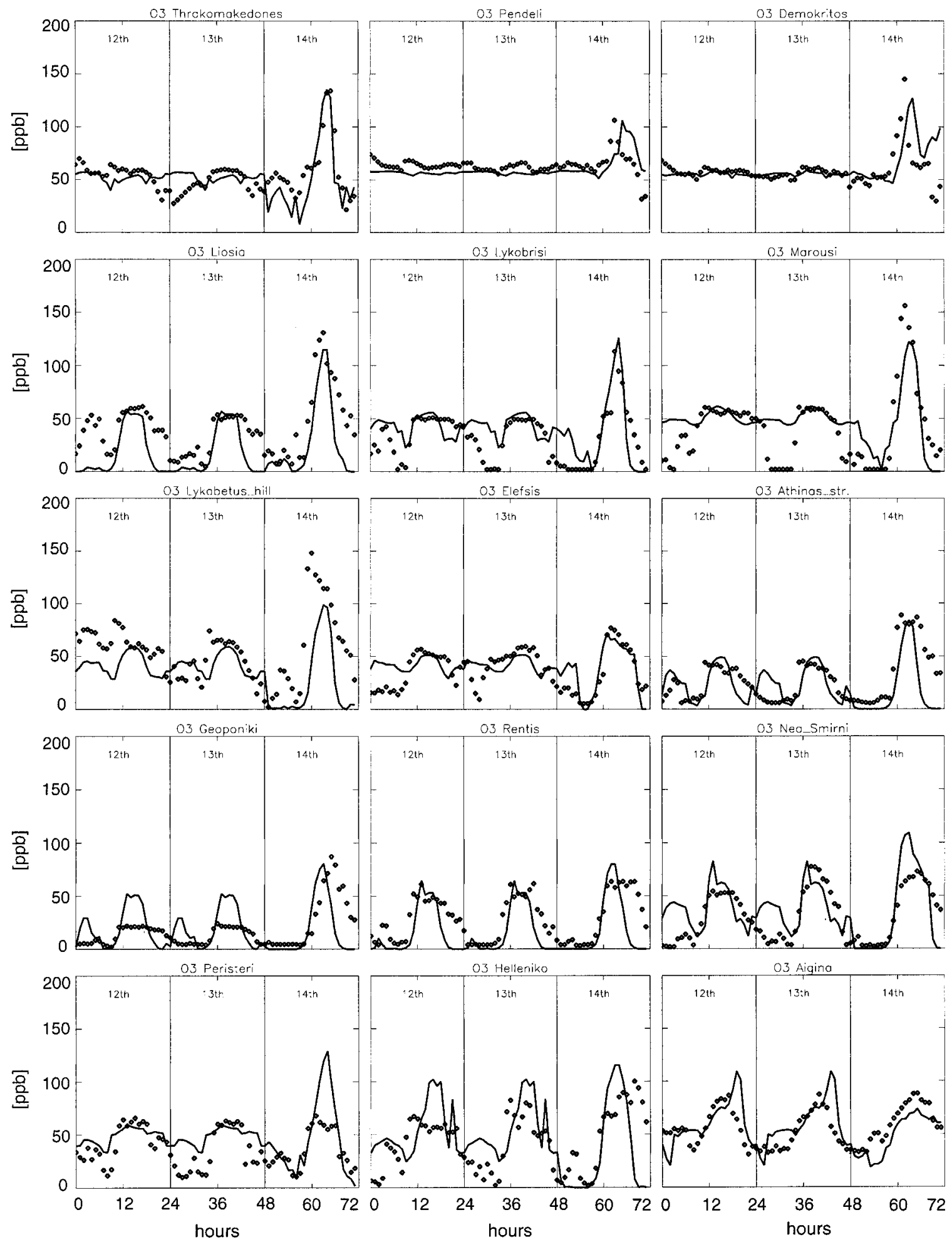

FIG. 9. Comparison between all available ozone ground measurements and model results (ppb) on 12-14 Sep. The solid line depicts model results, and dots represent measurements. 

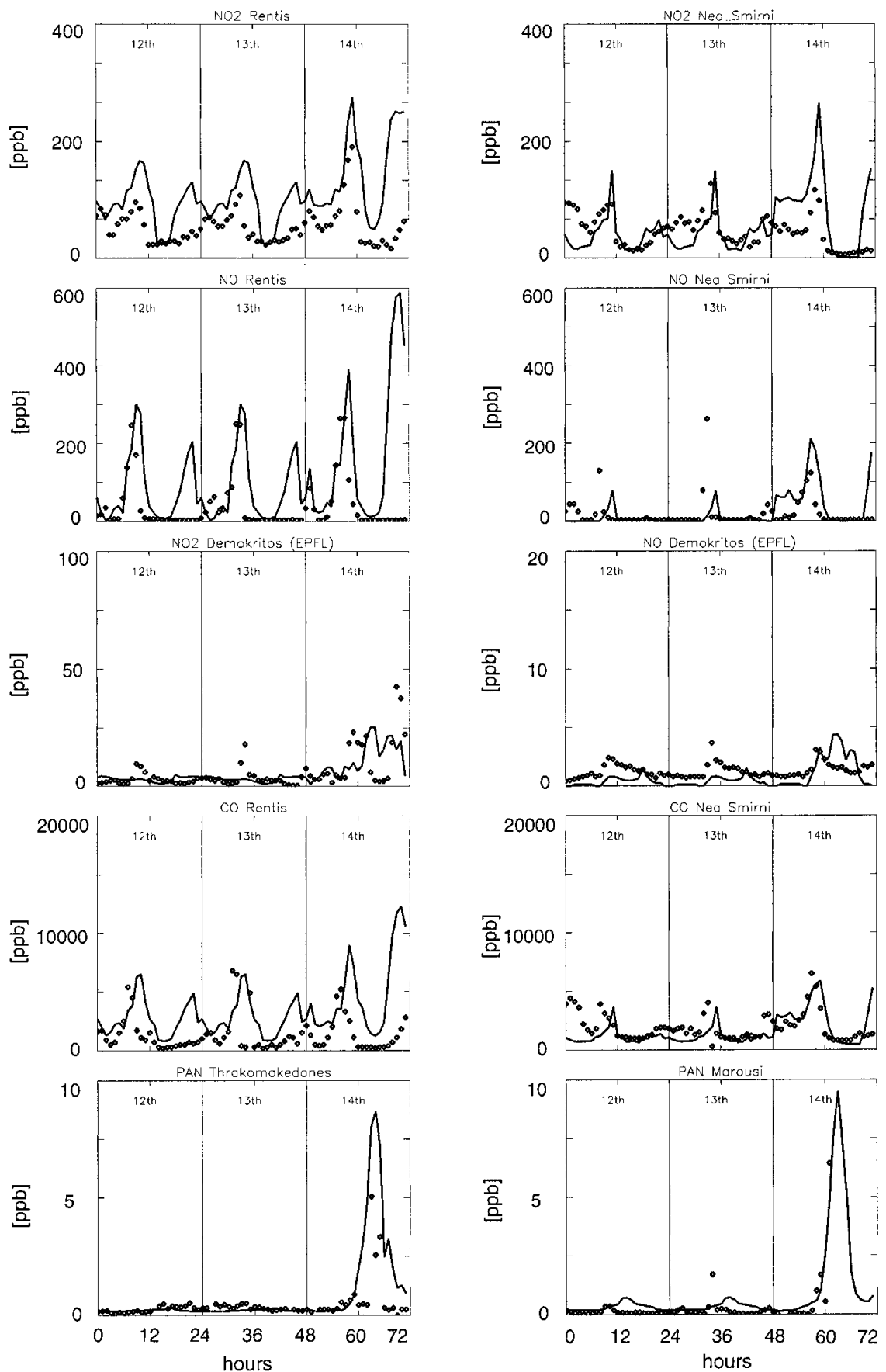

FIG. 10. Comparison between ground measurements and model results for $\mathrm{NO}_{2}, \mathrm{NO}, \mathrm{CO}$, and PAN on 12-14 Sep. The solid line depicts model results, and dots represent measurements. Note that not all the pollutants are measured at all locations.

a terrain-following coordinate system with 24 levels is used with grid spacing that increases from $30 \mathrm{~m}$ at the surface up to $1000 \mathrm{~m}$ near the model top (located at $8600 \mathrm{~m}$ ). This vertical grid stretching (ratio 1.2) is similar to that used in other studies, for example, Bornstein et al. (1996) and Poulos and Bossert (1995). In the current study, a viscous layer is used at the upper boundary
(Hoinka 1985) to prevent gravity-wave reflection. TVM-LCC is able to calculate meteorological processes and transport/chemical processes on different grids. For this study, the chemical grid has the same horizontal resolution as the meteorological one but without the eight boundary cells and has 11 vertical intervals that reach $3250 \mathrm{~m}$ above ground level (AGL). 


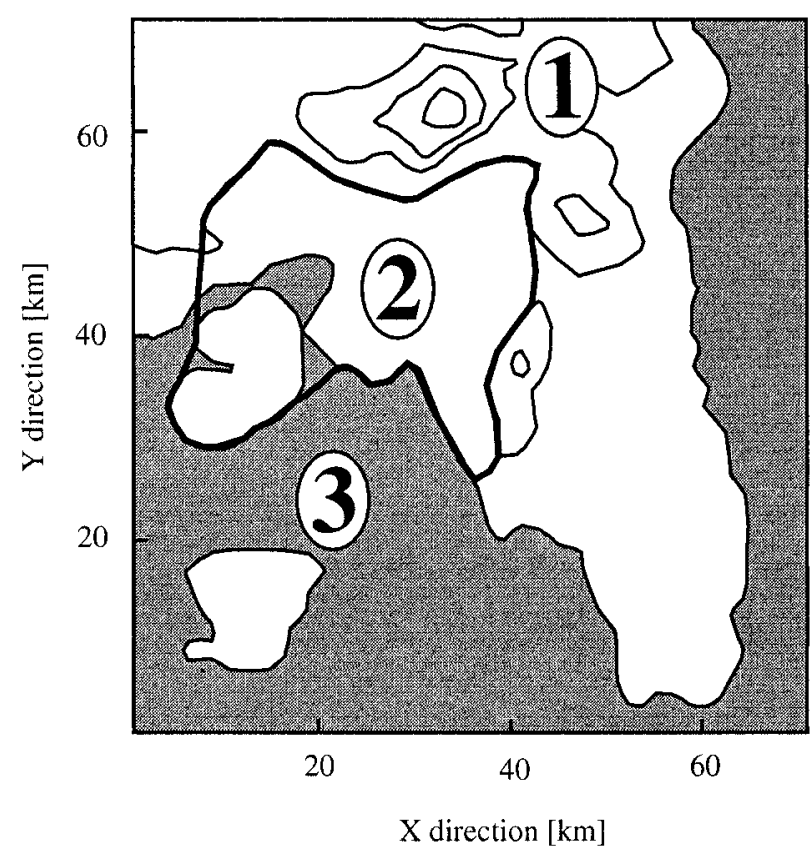

FIG. 11. Map of the three GAA regions on 12 Sep: the rural area (1), where ozone remains at the constant $60 \mathrm{ppb}$ background; the city (2), where ozone is destroyed at night and increases to $60 \mathrm{ppb}$ or slightly less during the day; and the area over the sea (3), where ozone increases during daytime to $80-90 \mathrm{ppb}$.

\section{2) INITIALIZATION AND BOUNDARY CONDITIONS}

For the dynamical calculations, each of the three daily simulations was performed separately. The simulations start at 2200 LT, with horizontally homogeneus initial conditions based on the vertical soundings of the Hellenikon Airport, and last for $26 \mathrm{~h}$. These soundings show a free tropospheric wind from the northwest with variable speed from $2 \mathrm{~m} \mathrm{~s}^{-1}$ (14 September) to $8 \mathrm{~m} \mathrm{~s}^{-1}$ (12 and 13 September; see Table 1). The geostrophic wind, atmospheric stability, and boundary conditions are fixed equal to the initial values and are not changed during the simulation period. The first $2 \mathrm{~h}$ of the simulation are considered to be an initialization period, and the results are analyzed starting from 0000 LT.

The chemical simulations start at midnight after the 2 $\mathrm{h}$ of initialization of the dynamics and last for $24 \mathrm{~h}$. The chemical initial conditions for 12 September are the results of a 1-day simulation with emissions, chemistry, diffusion, and advection (wind field equal to that of 12 September), starting from background values. The initial conditions for 13 and 14 September are the results of the simulation of the previous days. Chemical concentration background values are used as boundary conditions and are kept constant for the three days. These values are determined from 12 September flight measurements performed between 1300 and 1315 LT in the north of the domain that indicate $60 \mathrm{ppb}$ ozone, constant with height (Fig. 4), and very low $\mathrm{NO}_{\mathrm{x}}$ values (about $0.1 \mathrm{ppb}$ ), and from ground measurements of the stations in the north of the domain that show an ozone concentration of 60 ppb constant with time during 12 and 13 September. These ground conditions were not influenced by the city emissions because of the strong northerly synoptic wind.

\section{3) EMISSIONS}

The emissions used in this study are combined from two inventories. The data described in Ziomas et al. (1995) are used for the harbor, industry, and extraurban traffic, and traffic emissions in the city center and airport emissions are from Arvanitis et al. (1997) and Moussiopoulos et al. (1997). The emissions, which correspond to the early 1990 s, contain $\mathrm{NO}_{\mathrm{x}}$, carbon monoxide (CO), and hydrocarbons (split according to the chemical module requirements) in an interval of $2 \mathrm{~km} \times 2 \mathrm{~km}$ $\times 1 \mathrm{~h}$. The traffic and harbor sources are specified at the first level of the grid $(<30 \mathrm{~m})$, and the emission height is taken into account for industries in the Thriassion Plain and for airplanes.

All the three simulated days are weekdays, and no traffic regulations were imposed by the Greek authorities. Therefore, the expected traffic volume would be approximately the same for all three days. Pollution concentration variations can be attributed mainly to meteorological variations.

\section{Results}

Only the meteorological and chemical behavior for 12 and 14 September is described here, because the situation on 13 September is very similar to the one on 12 September (see Table 1 for presentation of largescale input parameters).

\section{a. 12 September 1994}

\section{1) AtMOSPHERIC CIRCULATION}

The nighttime model results show an interaction between the strong, northerly geostrophic wind and the mountains. Wind is deflected around the mountain range and is channeled within the passes (Fig. 5a). Downslope wind flows off of the mountains continue until they reach the sea. The winds are strong except in the wake of the Parnitha Mountains (city area), where they slow down. This slowing is confirmed by measurements at Geoponiki (Fig. 6b), where wind speed is less than 2 $\mathrm{m} \mathrm{s}^{-1}$. The actual low wind region probably is a few kilometers wider than it is in the model results (Fig. 5a), as seen, for example, at Geoponiki and Elefsis where modeled winds are much stronger than are the observed ones. The prevailing northerly wind direction is observed and modeled at the two other stations within the peninsula, Spata and Varkiza (Fig. 6a). At Aigina Island, a very weak wind (less than $1 \mathrm{~m} \mathrm{~s}^{-1}$ ) is measured and modeled, although the direction cannot be considered to be representative at such low speeds.

During daytime, sunlight heats the ground, and a tur- 
(a)

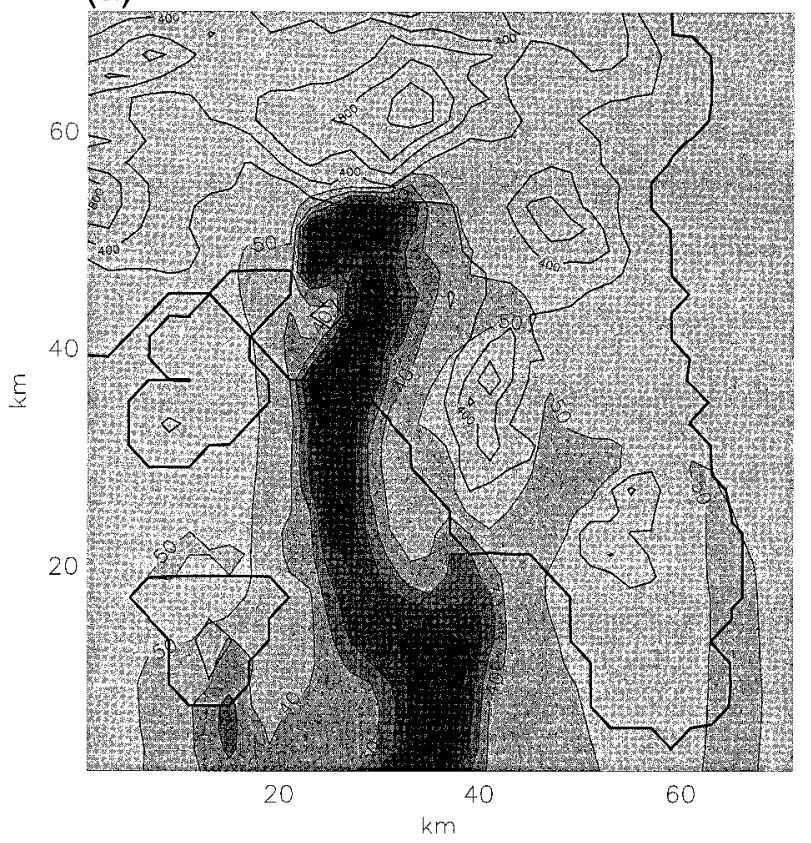

(c)

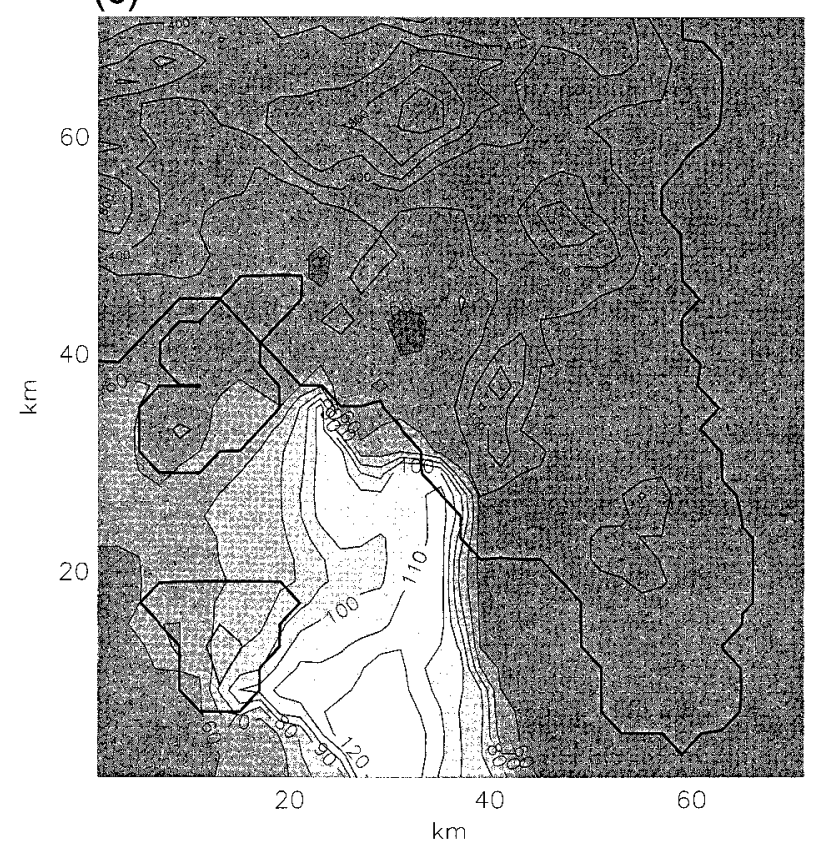

(b)

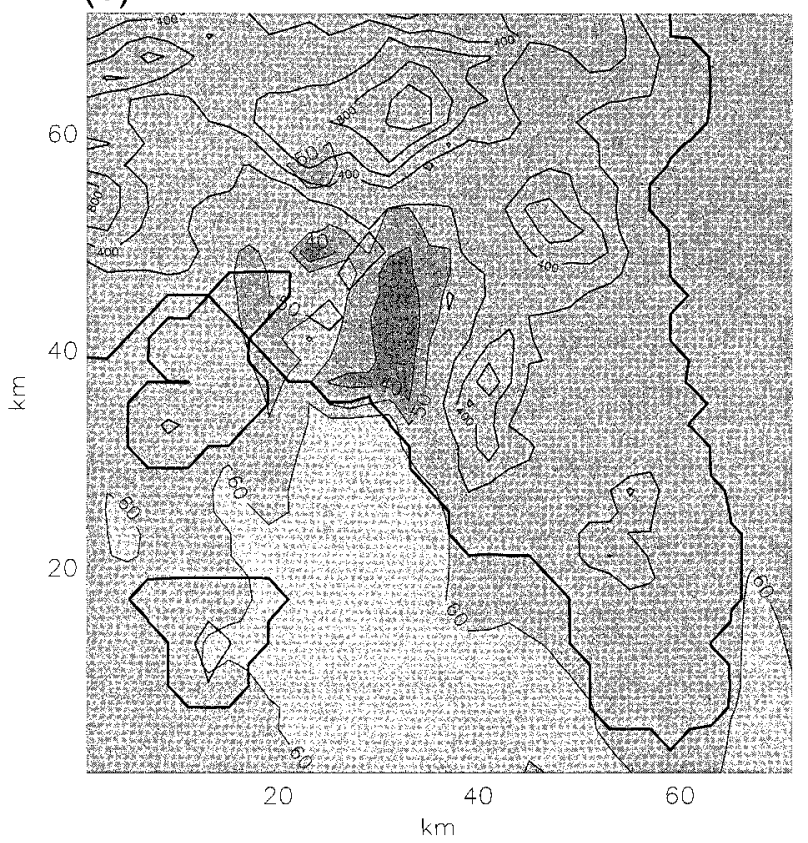

FIG. 12. Modeled ozone values (ppb) within the first vertical layer (30 m) on 12 Sep at (a) 0300, (b) 1200, and (c) 1600 LT.

bulent, unstable layer develops over land. The increased vertical turbulent diffusion generates a momentum transfer from higher levels to the ground, and surface wind speeds increase (Fig. 5b). Because of the geostrophic flow strength, a sea breeze cannot develop fully, and the sea-breeze front remains located a few kilo- meters behind the shoreline (Fig. 5c). For peninsula stations, an increase in wind speed during daytime without any change in wind direction is found in both measurements and model calculations (Fig. 6). In the city (Fig. 5c), a northeast wind of about $4 \mathrm{~m} \mathrm{~s}^{-1}$ is seen. At Aigina Island, the winds are light and variable. 


\section{2) Chemical conditions}

On 12 September, airborne instruments collected vertical profiles of $\mathrm{O}_{3}, \mathrm{NO}$, and $\mathrm{NO}_{2}$ concentrations between 1140 and 1410 LT (Klemm et al. 1998). The first vertical profile was measured in the northeast, upwind of the domain, and is representative of the boundary and background conditions (see above). The second vertical profile was obtained over Aigina Island (see Fig. 7 in which measurements are compared with model results) and indicates a value of about $80 \mathrm{ppb}$ of ozone up to 800-1000 $\mathrm{m}$ above mean sea level (MSL; the mixing layer height over the island) with $60 \mathrm{ppb}$ aloft (background). The presence of 80-90 ppb of ozone over the Saronic Gulf around noon is confirmed by the measurements collected along the horizontal aircraft paths at different heights. Both measurements and model results indicate ozone values of $60 \mathrm{ppb}$ upwind of the city and $80 \mathrm{ppb}$ downwind (Figs. 7, 8). This pattern may be caused by the fact that, during the night and early morning, the VOC and $\mathrm{NO}_{\mathrm{x}}$ emitted in the city are carried over the sea by the strong geostrophic wind. The strong atmospheric stability from the ground cooling dominates over the production of turbulence from vertical shear. Because the turbulence is weak, there is no vertical transport, and the pollutants are concentrated in a shallow layer. This interpretation is coherent with numerical results, although there are no available measurements to confirm it. A similar situation has been described for the U.S. city of Chicago (e.g., Sillman et al. 1993). At sunrise, ozone is formed efficiently within this layer but, since the sea breeze cannot penetrate deeply inland, this ozone stays over the sea. On the other hand, during daytime, the $\mathrm{NO}_{\mathrm{x}}$ and $\mathrm{VOC}$ emitted in the city are mixed vertically to higher levels by turbulence and are carried offshore by the combination of the return current and geostrophic wind. In these upper layers (between 300 and 500 m MSL), chemical compounds react with solar radiation to form a high-ozone concentration region. Agreement between model results and experimental data is fairly good, particularly over the sea (lower than $500 \mathrm{~m}$; Fig. 8) and over Aigina Island $\left(1000 \mathrm{~m}\right.$; Fig. 7), where the high $-\mathrm{O}_{3}$ concentration regions are reproduced well.

From the time evolution of $\mathrm{O}_{3}$ (Fig. 9), $\mathrm{NO}, \mathrm{NO}_{2}$, $\mathrm{CO}$, and peroxyacetyl nitrate (PAN) (Fig. 10) ground measurements, it is possible to distinguish three different regions over the greater Athens area (Fig. 11):

1) Zone 1: the upwind rural area. In this region, the primary pollutant concentrations are low [NO and $\mathrm{NO}_{2}$ concentrations are less than $15 \mathrm{ppb}$; for example, Demokritos (31 in Fig. 3) in Fig. 10], and $\mathrm{O}_{3}$ concentrations are steady and equal to the $60 \mathrm{ppb}$ background level [e.g., the stations of Thrakomakedones (1), Demokritos (31), or Pendeli (3) in Fig. 9].

2) Zone 2: downtown. The primary pollutant concentrations are very high, especially in the early morning when turbulence is still low and the automobile traffic increases: peaks of $\mathrm{NO}_{2}$ (greater than $100 \mathrm{ppb}$ ),
NO, and CO (respectively, 100 and $2500 \mathrm{ppb}$ ) are found [e.g., Rentis (26) and Nea Smirni (30) in Fig. 10]. Because of the high $\mathrm{NO}_{x}$ concentrations, $\mathrm{O}_{3}$ is totally consumed during the night and increases to $60 \mathrm{ppb}$ (or slightly less) during the day [Athens Street (24), Nea Smirni (30), Rentis (26), Geoponiki (22), Liosia (11), and Lykobrisi (12)].

3) Zone 3: the downwind area over the sea. The $\mathrm{O}_{3}$ increases during daytime to 80-90 ppb [Aigina (6)], and the $\mathrm{NO}_{\mathrm{x}}$ concentrations (not shown) are low $(<2$ $\mathrm{ppb}$ for $\mathrm{NO}$ and $<10 \mathrm{ppb}$ for $\mathrm{NO}_{2}$ ).

For these first two days, model results agree very well with the constant $60 \mathrm{ppb}$ ozone and very low $\mathrm{NO}_{\mathrm{x}}$ and PAN values measured at the stations in the north of the domain (Demokritos, Pendeli, Thrakomamkedones). For the city stations, the model also is able to reproduce the diurnal behavior of ozone (with an overestimation during the day at Geoponiki and during the night at Marousi). For $\mathrm{NO}, \mathrm{NO}_{2}$, and $\mathrm{CO}$, the model results catch the morning peak but overestimate concentrations in the evening. In general, the distribution of pollutant concentrations is reproduced well by the model.

With use of a map of computed ozone concentrations at the first model level (30 m AGL; Fig. 12), the different distributions (Fig. 11) can be explained in each zone. In zone 1 , northerly winds bring background ozone into the domain, and mixing ratios remain approximately constant (60 ppb for $\mathrm{O}_{3}$ less than 2-3 ppb for $\mathrm{NO}_{2}$ and $\mathrm{NO}$ ). In zone 2 during the night, $\mathrm{NO}_{\mathrm{x}}$ concentrations reach very high values because emissions are trapped near the ground by strong atmospheric stability and ozone consequently is destroyed rapidly. Because the wind in this area blows toward the sea, pollution is dispersed over the Saronic Gulf (zone 3) (Fig. 12a). In the early morning, the sea-breeze regime is not present yet, and transport of city-emitted $\mathrm{NO}_{\mathrm{x}}$ and VOC toward the sea continues. At the same time, $\mathrm{NO}_{2}$ photodissociation starts, and ozone increases to reach the background level (Fig. 12b). In the early afternoon, the $\mathrm{NO}_{\mathrm{x}}$ and VOC that accumulated during the night and morning over the sea (zone 3 ) in a very shallow layer favor ozone production. A maximum is formed over the Saronic Gulf [more than $90 \mathrm{ppb}$ of ozone are measured and computed at Aigina Island (Fig. 12c)], but because the sea breeze stops a few kilometers behind the shoreline, this ozone does not reach the monitoring stations located on the peninsula.

In summary, the strong northerly synoptic wind on 12 and 13 September carried pollution over the sea during the night and early morning, where it stayed during the day because sea breezes were not strong enough to penetrate inland. These phenomena are reproduced well by the model.

\section{b. 14 September 1994}

\section{1) AtMOSPHERIC CIRCULATION}

On 14 September, the synoptic situation changed, as indicated by the Hellenikon airport vertical sounding 
(a)

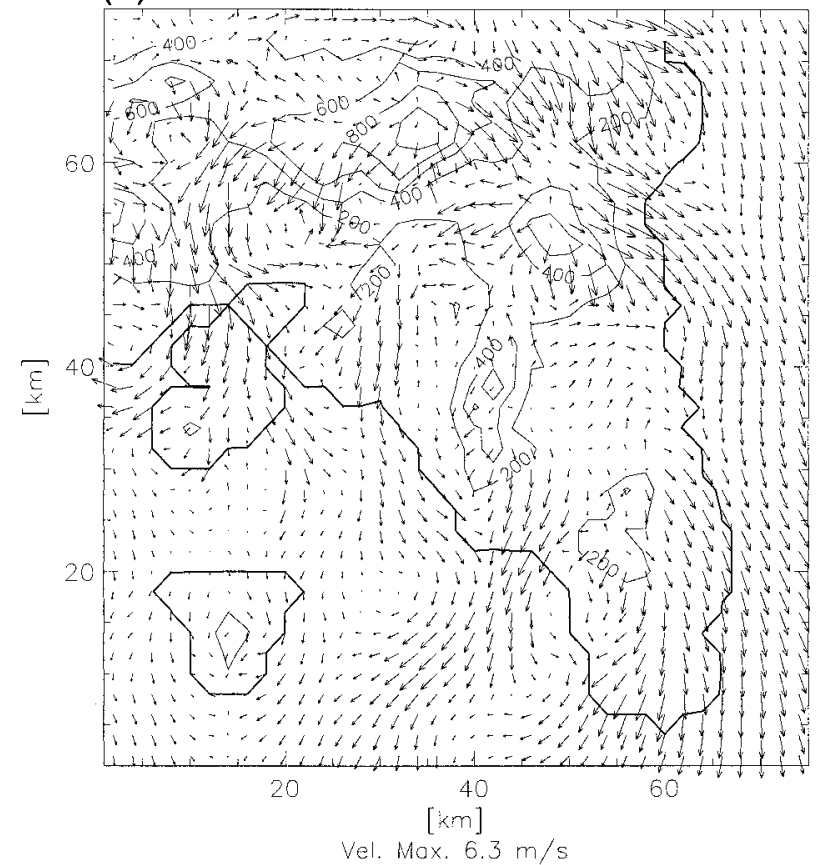

(c)

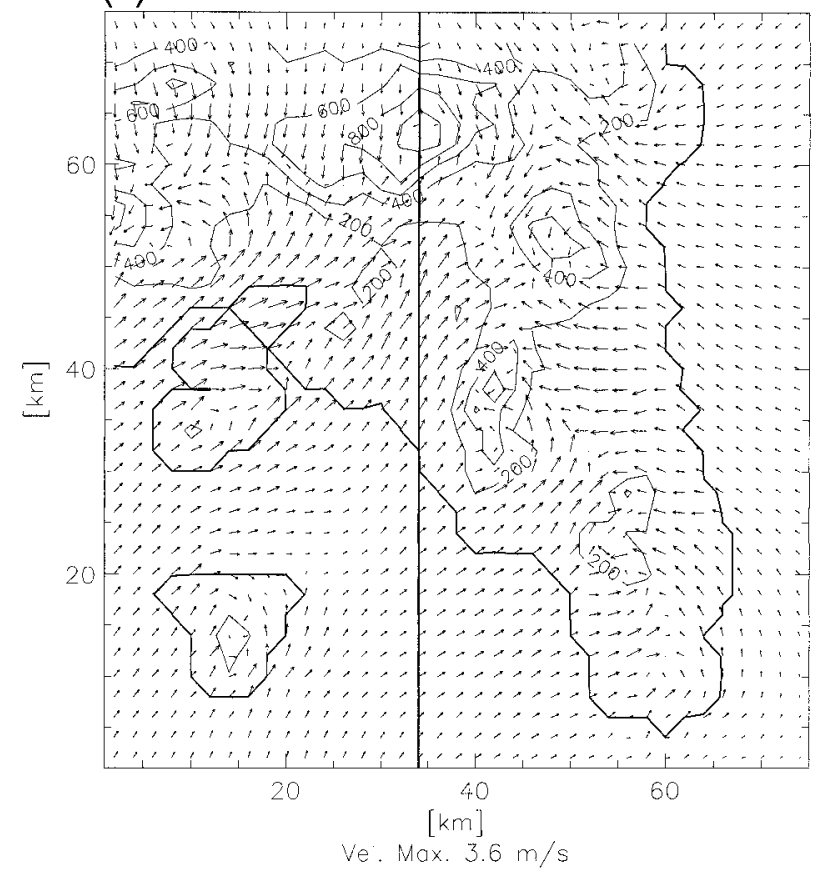

(b)

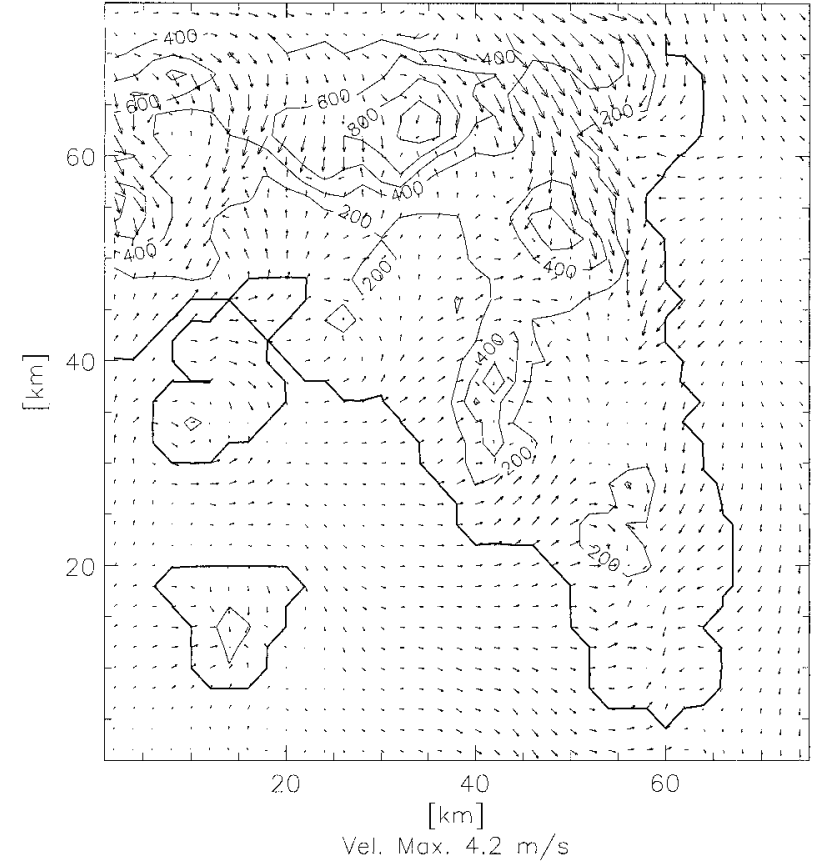

(d)

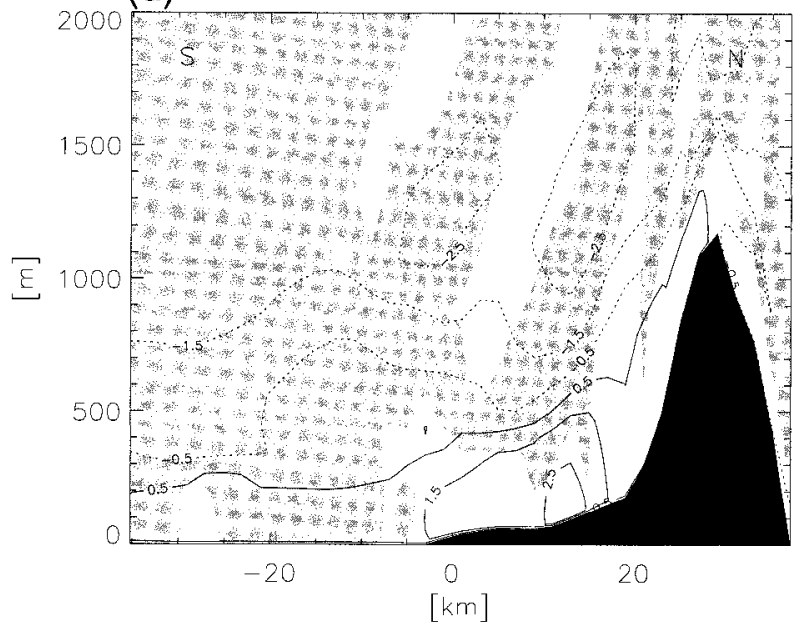

FIG. 13. Modeled wind fields at $15 \mathrm{~m} \mathrm{AGL}$ on $14 \mathrm{Sep}$ at (a) 0300, (b) 1200, and (c) 1600 LT. [The vertical line in (c) shows the vertical cross section location.] Scaling vector is the same for all the graphics. (d) Vertical cross section at 1600 LT of the horizontal wind component (solid lines represent southerly wind, dotted lines represent northerly wind). Gray areas show the vertical wind velocity (light for positive and dark for negative).

that shows a $2 \mathrm{~m} \mathrm{~s}^{-1}$ northerly geostrophic wind, which is much lower than that on the two previous days. The local circulation (sea-and breezes and slope winds) consequently develops better.
Results show that, during the night, the general circulation over the Attica peninsula is very weak, as confirmed by wind measurements (all $<2 \mathrm{~m} \mathrm{~s}^{-1}$; Fig. 6b). The modeled wind field (Fig. 13a) at 0300 LT shows 


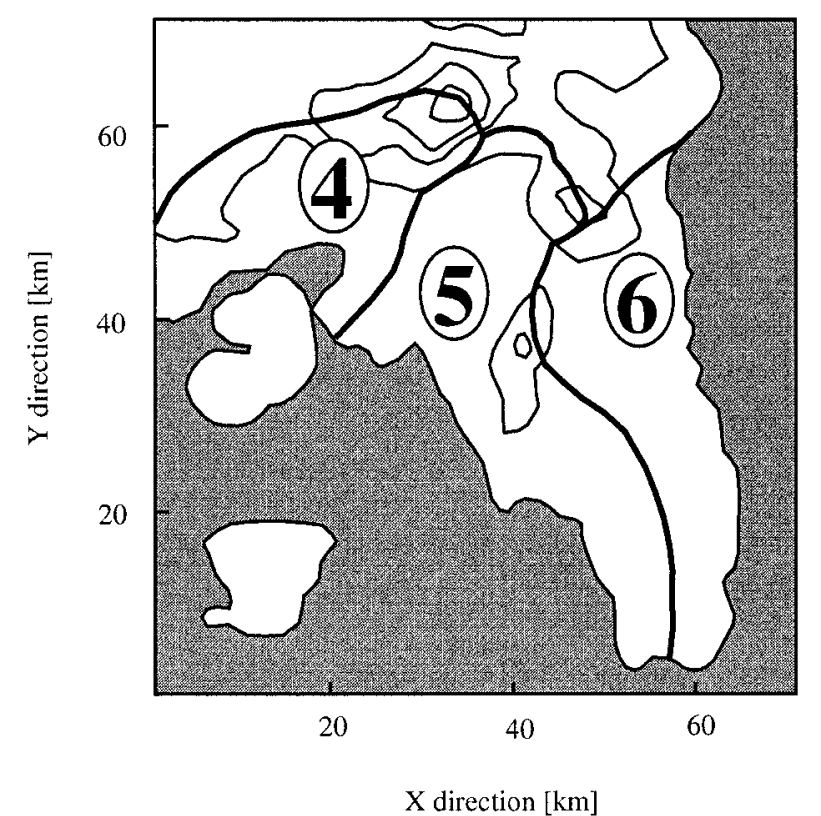

FIG. 14. Map of the three GAA regions on 14 Sep: the Thriasson Plain (4), the Athens basin (5), and the Mesogia Plain (6). These three areas are defined using the main wind field convergence zone at 1600 LT (Fig. 13c).

katabatic flows that reach the sea. In the western part of the domain, breezes are channeled in the Thriassion Plain to the coast (at Salamina Island). This behavior is confirmed by Elefsis observations (Fig. 6) that show a weak northeast wind during night. The wind speeds remain weak in the city (see Geoponiki). Between 0900 and 1100 LT, sea breezes start to develop over the whole peninsula, and wind directions at the coastal stations (Varkiza, Elefsis, Spata, and Geoponiki) experience a wind shift of $180^{\circ}$ associated with a wind speed minimum (Fig. 6). At noon, the sea breezes are developed fully, but wind speed remains weak (Fig. 13b).

At 1600 LT, upslope winds intensify, and the sea breezes then penetrate the whole Attica Peninsula (Fig. 13c). The vertical cross section (Fig. 13d) shows the sea breeze, the slope wind, and the return current above. It is possible to identify three different sea-breeze systems; the first develops in the Thriassion Plain area (called zone 4 in Fig. 14), the second in the city (zone 5 ), and the third is located in the Mesogia Plain (zone $6)$. These phenomena are captured well by the TVM simulations.

\section{2) Chemical conditions}

During the night, the situation is similar to that on 12 and 13 September; that is, the city-emitted $\mathrm{NO}_{\mathrm{x}}$ and VOC (zone 2) are carried over the sea (zone 3 ). A region of low $\mathrm{O}_{3}$ (Fig. 15a), high $\mathrm{NO}_{x}$, and VOC consequently forms in the city and over the sea.

During daytime, the pollutant distribution is influenced strongly by the three different sea-breeze systems described above (Fig. 15b). In zones 4 and 5, the sea breeze penetrates inland and carries pollution to the northern and eastern parts of the peninsula. Larger $\mathrm{O}_{3}$ and PAN maxima than on the previous days (i.e., larger than $90 \mathrm{ppb}$ for $\mathrm{O}_{3}$, and about 5-7 ppb for PAN) are observed and simulated (Figs. 15c, 9, and 10), in particular at Thrakomakedones (1), Elefsis (2), Pendeli (3), Hellenikon Airport (8), Liosia (11), Lykobrisi (12), Marousi (14), Lykabettus Hill (23), and Demokritos (31). At all these locations (Fig. 3), simulated ozone concentrations exceed the 90-ppb limit (Fig. 9), indicating the capability of the model to reproduce the photochemical smog formation and evolution. A closer analysis of the results does identify some differences with measurements, the main ones being the following.

- The model overestimates the spatial extent of the high ozone region [see Peristeri (15) and Nea Smirni (30) at which the 90-ppb limit is exceeded only in the model results].

- The intensity and timing of the ozone peak can differ slightly, especially at Demokritos (31) at which the ozone peak only appears for a short time. There, the model computes $126 \mathrm{ppb}$ at 1600 LT instead of the measured $144 \mathrm{ppb}$ at $1400 \mathrm{LT}$.

Complementary information on the ozone and photochemical smog vertical structure at Demokritos can be obtained from lidar measurements. In Fig. 16, measured vertical profiles are compared with model results. At $1221 \mathrm{LT}$, measurements and model results both show the 60-ppb ozone background values (Fig. 16a). Later, observations show a strong ozone peak (from 1327 to 1409 LT) that extends from the surface to higher levels (Fig. 16). This ozone increase is reproduced well although a certain delay is seen. Measurements at this station are especially difficult to reproduce because it lies on the convergence line of two sea-breeze systems (zones 5 and 6). In the early afternoon (1300 LT), the sea breeze that developed over the city prevails and advects ozone rich air (144 ppb) to Demokritos. In contrast, the eastern sea breeze that dominates later on (at 1430 LT) brings relatively clean air (few emissions are present on this side of the peninsula).

In conclusion, the simulation correctly reproduces the sequence of pollution events that occurred on 14 September. During the night, pollutants are displaced over the sea (zones 2 to 3). After 1000 LT, the sea breeze starts to develop in zones 4, 5, and 6, and ozone is formed in the northern and eastern parts of the domain. Last, the sea breeze forming in the Mesogia Plain (zone 6) prevails and pushes the ozone maximum to the north.

\section{Conclusions}

Three-dimensional photochemical model simulations have been performed for a 3-day episode in the greater Athens area. For different pollutants $\left(\mathrm{O}_{3}, \mathrm{NO}, \mathrm{NO}_{2}, \mathrm{CO}\right.$, and PAN), model results have been compared with a 
(a)
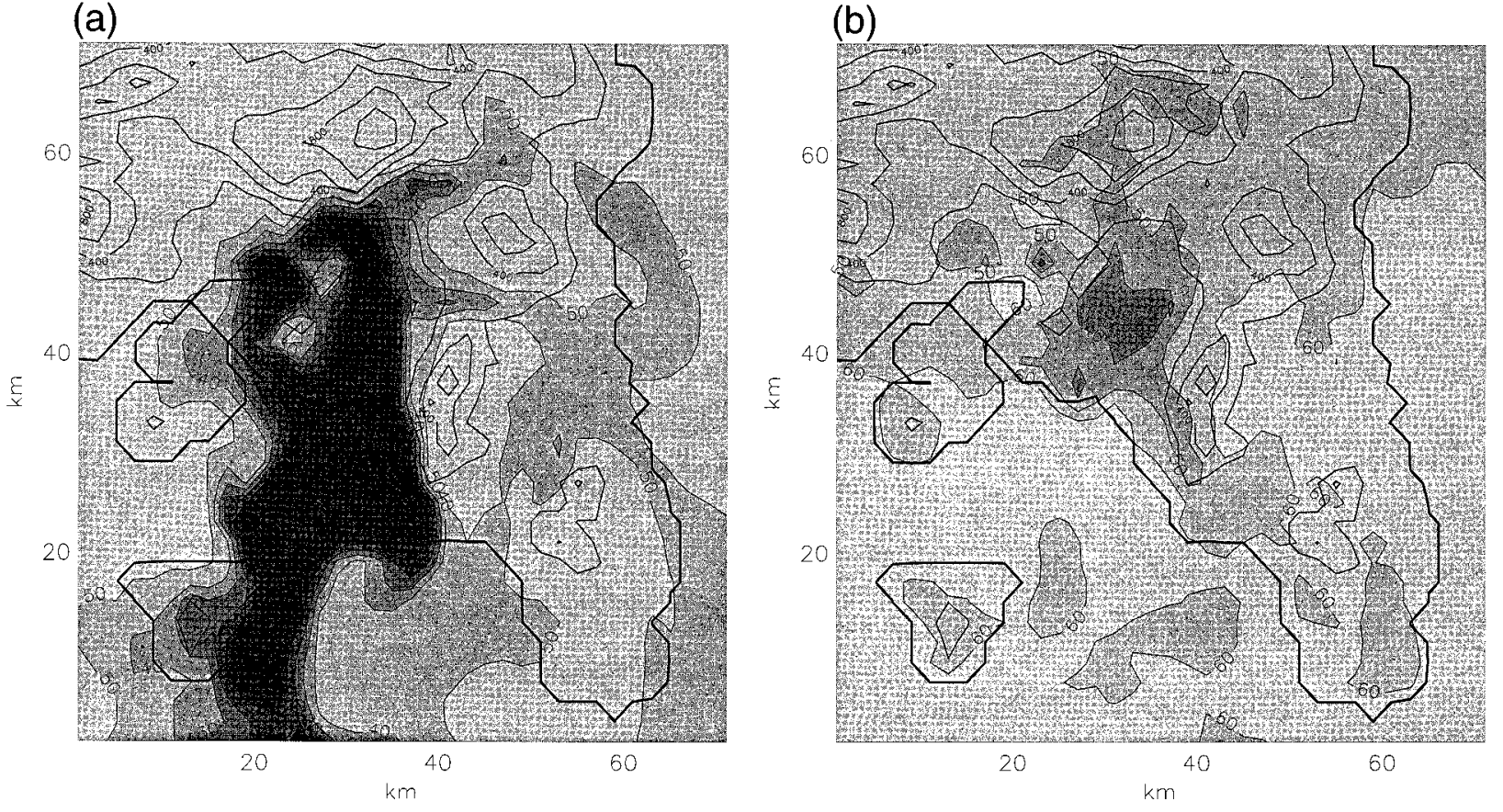

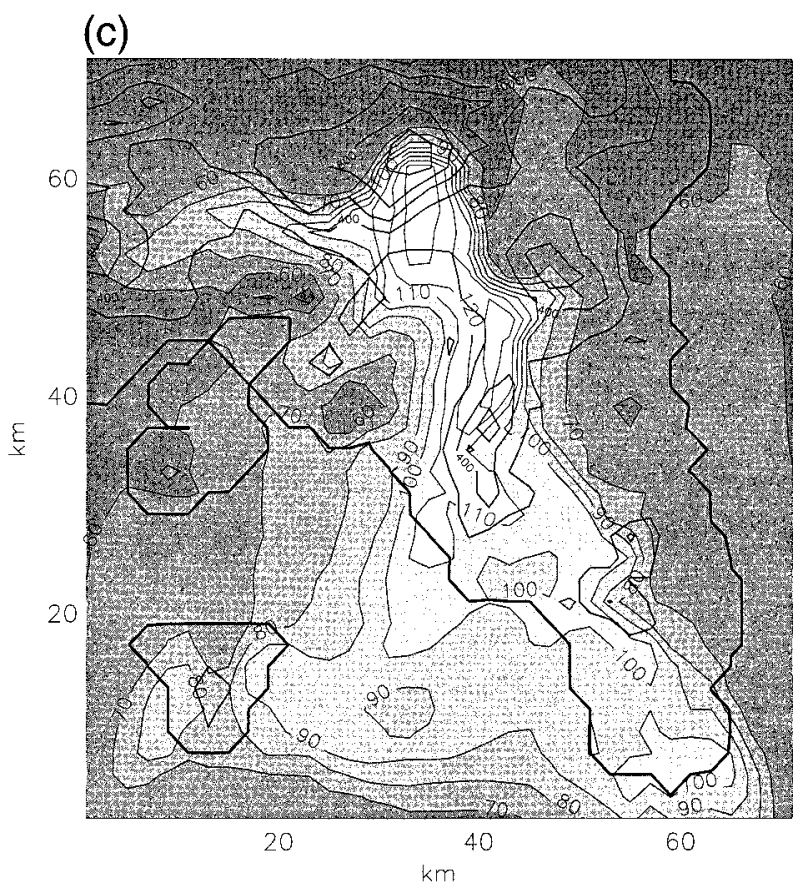

FIG. 15. Modeled ozone values within the first vertical layer (30 m) on $14 \mathrm{Sep}$ at (a) 0300, (b) 1200, and (c) 1600 LT.

large number of ground measurements that have allowed the determination of their time-dependent distribution in GAA. In the vertical, model results have been compared with the observations gathered from an aircraft and a lidar. The comparison between field measurements and model results shows that the dynamical photochemical TVM-LCC model was able to reproduce the main characteristics of the photochemical episode of 12-14
September 1994 over GAA. In addition, the model simulations have helped in interpreting field measurements. For example, the model simulated the observed high ozone concentrations aloft that are caused by the vertical transport of the pollutant over the slope of the mountain to the higher level and then over the Saronic Gulf.

The flow model results have shown the convergence of three breeze systems over the Attica peninsula. The 

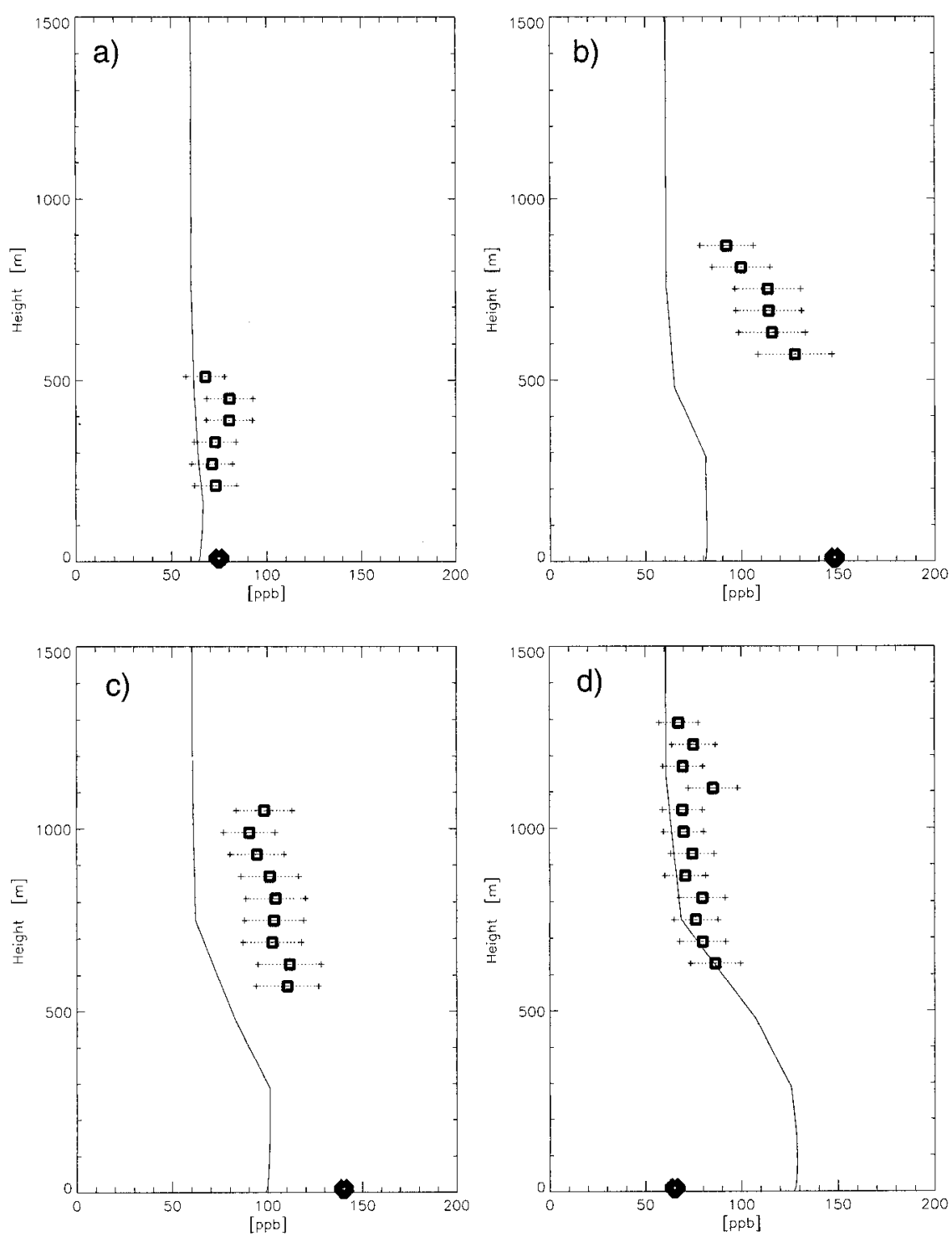

FIG. 16. Comparison between lidar measurements and model results at Demokritos on $14 \mathrm{Sep}$ at: (a) 1221, (b) 1327, (c) 1409, and (d) 1525 LT. Solid lines represent the model results, the black squares represent the lidar measurements (dotted lines represent the measurement uncertainty), and diamonds represent the ground measurements.

pollution concentrations and the location of the ozone maximum concentration in GAA are linked strongly to the degree of penetration of these three sea-breeze systems into the Attica Peninsula: the first in the Thriassion Plain (zone 4), the second in the city (zone 5), and the third in the Mesogia Plain (zone 6). The extension of these three systems depends on the strength and direction of the synoptic forcing. On two of the days considered, 12 and 13 September, a strong $\left(8 \mathrm{~m} \mathrm{~s}^{-1}\right)$, northerly synoptic wind inhibited a deep inland penetration of the sea breezes. In this case, maximum ozone concentrations are computed over the sea in the southern Athens basin, and concentrations remain relatively low (less than $100 \mathrm{ppb}$ ) in the peninsula. In contrast, on 14
September, the synoptic wind was much weaker $(2 \mathrm{~m}$ $\mathrm{s}^{-1}$ ) and allowed for the formation and penetration inland of the three sea-breeze systems. In this case, maximum ozone concentrations (156 ppb) were recorded north and east of the city.

The TVM-LCC model thus has been shown to reproduce the main pollution features over GAA. In part II of this paper (Grossi et al. 2000), different emission scenarios are studied, with special emphasis on 1) the impact of night versus daytime emissions, 2) the contribution of each basin's emissions (Elefsis vs Athens), and 3 ) the recycling of air pollutants from one day to the other, to understand the physical and chemical mechanisms responsible for the photochemical smog. 
Acknowledgments. The authors would like to thank Dr. S. Galmarini for his help in preparing this paper. This work was supported by EPFL and the bid committee for the "Athens 2004" Olympics.

\section{REFERENCES}

Arvanitis, T., T. Nitis, G. Theodoridis, P. M. Tourlou, C. Naneris, and N. Moussiopoulos, 1997: Synthesis of the 2004 emission inventory. Athens 2004 Air Quality, N. Moussiopoulos and S. Papagrigoriou, Eds., Athens 2004 Olympics Bid Committee, 60-70.

Bornstein R., P. Thunis, P. Grossi, and G. Schayes, 1996: Topographic vorticity-mode mesoscale- $\beta$ (TVM) model. Part II. Evaluation. J. Appl. Meteor., 35, 1824-1834.

Businger, J. A., 1975: Interactions of sea and atmosphere. Rev. Geophys. Space Phys., 13, 720-726.

Clappier, A., 1998: A correction method for use in multidimensional time-splitting advection algorithms: Application to two- and three-dimensional transport. Mon. Wea Rev., 126, 232-242.

Collella, P., and P. Woodward, 1984: The piece-wise parabolic method (PPM) for gas dynamical simulations. J. Comput. Phys., 54, 174201.

De Ridder, K., and G. Schayes, 1997: The IAGL land surface model. J. Appl. Meteor., 36, 167-181.

Durieux, E., L. Fiorani, B. Calpini, M. Flamm, L. Jaquet, and H. van den Bergh, 1998: Tropospheric ozone measurements over the Great Athens Area during the MEDCAPHOT-TRACE campaign with a new shot-per-shot DIAL instrument: Experimental system and results. Atmos. Environ., 32, 2142-2150.

Fiorani, L., B. Calpini, L. Jaquet, H. van den Bergh, and E. Durieux, 1997: Correction scheme for experimental biases in differential absorption lidar tropospheric ozone measurements based on the analysis of shot per shot data samples. Appl. Opt., 36, 68576863.

,,,,---- and $-1998:$ A combined determination of wind velocities and ozone concentrations for a first measurement of ozone fluxes with a DIAL instrument during the MEDCAPHOT-TRACE campaign. Atmos. Environ., 32, 2151-2159.

Grossi, P., J.-M. Giovannoni, and A. G. Russell, 1996: Intercomparison of meteorological models applied to the Athens area and the effect on photochemical pollutant predictions. J. Appl. Meteor., 35, 993-1008.

— - P. Thunis, A. Martilli, and A. Clappier, 2000: Effect of sea breeze on air pollution in the greater Athens area. Part II: Analysis of different emission scenarios. J. Appl. Meteor., 39, 563575.

Harley, R. A., A. G. Russell, G. J. McRae, G. R. Cass, and J. H. Seinfeld, 1993: Photochemical modeling of the Southern California Air Quality Study. Environ. Sci. Technol., 27, 378-388.

Hoinka, K. P., 1985: A comparison of numerical simulation of hydrostatic flow over mountains with observations. Mon. Wea. Rev., 113, 719-735.

Kallos, G., P. Kassomenos, and R. A. Pielke, 1993: Synoptic and mesoscale weather conditions during air pollution episodes in Athens, Greece. Bound.-Layer Meteor., 62, 163-184.

Klemm, O., I. C. Ziomas, D. Balis, P. Suppan, J. Slemr, R. Romero, and L. G. Vyras, 1998: A summer air-pollution study in Athens, Greece. Atmos. Environ., 32, 2071-2087.

Louis, J.-F., 1979: A parametric model of vertical eddy fluxes in the atmosphere. Bound.-Layer Meteor., 17, 187-202.

Lu, R., and R. P. Turco, 1996: Ozone distributions over the Los Angeles Basin: Three-dimensional simulations with the SMOG model. Atmos. Environ., 30, 4155-4176.

Lurmann, F. W., W. P. Carter, and L. A. Coyner, 1987: A surrogate species chemical reaction mechanism for urban-scale air quality simulation models. Part I: Adaptation of the mechanism. EPA Rep. 600/3-87/014A, 211 pp. [Available from National Technical Information Service, 5285 Port Royal Road, Springfield, VA 22161.]

Mantis, H. T., C. C. Repapis, C. S. Zerefos, and J. C. Ziomas, 1992: Assessment of the potential for photochemical air pollution in Athens: A comparison of emissions and air-pollutant levels in Athens with those in Los Angeles. J. Appl. Meteor., 31, 14671476.

McRae, G. J., F. H. Shair, and J. H. Seinfeld, 1981: Convective downmixing of plumes in a coastal environment. J. Appl. Meteor., 20, 1312-1324.

Melas, D., I. C. Ziomas, and C. S. Zerefos, 1995: Boundary layer dynamics in an urban coastal environment under sea breeze conditions. Atmos. Environ., 29, 3605-3617.

Moussiopoulos, N., P. Sahm, and Ch. Kessler, 1995: Numerical simulation of photochemical smog in Athens, Greece-A case study. Atmos. Environ., 29, 3619-3632.

,-- K. Karatzas, S. Papalexiou, and A. Karagiannidis, 1997: Assessing the impact of the new Athens airport to urban air quality with contemporary air pollution models. Atmos. Environ., 31, 1497-1511.

Nester, K., 1995: Influence of sea breeze flows on air pollution over the Attica Peninsula. Atmos. Environ., 29, 3655-3670.

Polous, G. S., and J. E. Bossert, 1995: An observational and prognostic numerical investigation of complex terrain dispersion. $J$. Appl. Meteor., 34, 650-660.

Ruggaber, A., R. Dlugi, and T. Nakajima, 1994: Modelling radiation quantities and photolysis frequencies in the troposphere. $J$. Atmos. Chem., 18, 171-210.

Schayes, G., P. Thunis, and R. Bornstein, 1996: Topographic vorticitymode mesoscale- $\beta$ (TVM) model. Part I: Formulation. J. Appl. Meteor., 35, 1815-1823.

Schoulepnikoff, L., H. van den Bergh, V. Mitev, and B. Calpini, 1998: Tropospheric air pollution monitoring lidar. The Encyclopedia of Environmental Analysis and Remediation, R. A. Meyers, Ed., John Wiley and Sons, 4873-4909.

Sillman, S., P. J. Samson, and J. M. Masters, 1993: Ozone production in urban plumes transported over water: Photochemical model and case studies in the northeastern and midwestern United States. J. Geophys. Res., 98, 12 687-12 699.

Svensson, G., 1995: Mesoscale modeling of chemical and meteorological processes in the atmosphere. Ph.D. dissertation, Uppsala University, Uppsala, Sweden.

Therry, G., and P. Lacarrère, 1983: Improving the eddy kinetic energy model for planetary boundary layer description. Bound.-Layer Meteor., 25, 63-88.

Thunis, P., 1995: Formulation and evaluation of a non-hydrostatic vorticity-mode mesoscale model. Ph.D. dissertation, Université Catholique de Louvain-la-Neuve, Louvain-la-Neuve, Belgium, $151 \mathrm{pp}$.

Varvayanni, M., N. Catsaros, J. G. Bartzis, K. Konte, and G. M. Horsch, 1995: Wind flow simulation over the greater Athens area with highly resolved topography. Atmos. Environ., 29, 3593-3604.

Young, T. R., and J. P. Boris, 1977: A numerical technique for solving stiff ordinary differential equations associated with the chemical kinetics of reactive flow problems. J. Phys. Chem., 81, 24242427.

Ziomas, I. C., and Coauthors, 1995: A contribution to the study of photochemical smog in the greater Athens area. Beitr. Phys. Atmos., 68, 191-203.

, P. Tzoumaka, D. Balis, D. Melas, C. S. Zerefos, S. Christos, and O. Klemm, 1998: Ozone episodes in Athens, Greece. A modelling approach using data from the MEDCAPHOT-TRACE. Atmos. Environ., 32, 2313-2321. 